\title{
Pelatihan Motivasi Berwirausaha Pada Survivor Bipolar Di Komunitas Bipolar Care Indonesia Yogyakarta
}

\author{
Andhita Dyorita Khoiryasdien*, Annisa Warastri \\ Fakultas Ekonomi, Ilmu Sosial dan Humaniora \\ Universitas 'Aisyiyah Yogyakarta \\ email: dyorita.kh@unisayogya.ac.id
}

\begin{abstract}
Bipolar disorder is a psychiatric disorder in which the sufferer has episodes of mania and depression. The difference between bipolar disorder and those who don't suffer from bipolar disorder is that people with bipolar disorder will feel sad or happy without the need for a clear reason. Bipolar survivors can still move normally under stable conditions. However, the negative community stigma of mental disorders make it difficult for bipolar survivors to find work and become unproductive. Bipolar survivors only get education related to mental health and pharmacy all this time. Bipolar survivors need education about development and empowerment. Then training is needed that provides education to bipolar survivors on motivation in entrepreneurship. The result is increased understanding of participants in managing emotions, motivation, opportunities and business innovation. In addition, participants also succeeded in preparing business plans.
\end{abstract}

Keywords: Babadotan, vegetable insecticides, flies, air freshener,Tuan Naran

\begin{abstract}
Abstrak
Gangguan bipolar adalah gangguan kejiwaan dimana penderitanya mempunyai episode mania dan depresi. Perbedaan yang mendasar antara orang dengan gangguan bipolar dan yang tidak menderita bipolar adalah orang dengan bipolar akan merasa sedih atau gembira tanpa perlu suatu alasan yang jelas. Meskipun begitu, survivor bipolar masih dapat beraktivitas dengan normal dalam kondisi stabil. Stigma negatif masyarakat pada gangguan jiwa menyebabkan survivor bipolar sulit mendapatkan pekerjaan sehingga menjadi tidak produktif. Selama ini survivor bipolar hanya mendapatkan edukasi yang terkait dengan kesehatan mental dan farmaka. Survivor bipolar membutuhkan edukasi mengenai pengembangan dan pemberdayaan. Oleh karena itu, dibutuhkan pelatihan yang memberikan edukasi pada survivor bipolar mengenai motivasi dalam berwirausaha. Hasilnya pemahaman survivor meningkat dalam pengelolaan emosi, motivasi, peluang dan inovasi bisnis. Selain itu, peserta juga berhasil dalam menyusun perencanaan bisnis.
\end{abstract}

Kata Kunci: survivor bipolar, bipolar care indonesia, motivasi berwirausaha

\section{PENDAHULUAN}

\subsection{Analisis Situasi}

Kesehatan merupakan sumber daya manusia yang paling penting. Kesehatan tersebut mencakup kesehatan fisik dan psikis. Tanpa kesehatan yang baik, manusia pasti tidak bisa memaksimalkan kinerjanya sehingga kurang produktif. Hal tersebut juga dialami oleh para penderita gangguan Bipolar atau yang biasa disebut dengan survivor bipolar. Gangguan bipolar atau yang biasa disebut dengan gangguan mood mempunyai dua fase yaitu fase depresi 
dan fase mania [1]. Fase depresi berpusat pada emosi dimana emosi seseorang berada dalam kondisi kesedihan yang sangat ekstrim, sedangkan serta kondisi sangat senang secara berlebihan dan mudah terstimulus atau yang biasa disebut dengan kondisi mania. Perbedaan yang mendasar antara orang dengan gangguan bipolar dan yang tidak menderita bipolar adalah terkadang orang dengan bipolar akan merasa sedih atau gembira tanpa perlu suatu alasan yang jelas [2] Depresi dan Mania sangat membahayakan penderita karena saat kondisi mania, penderita bisa nekat melakukan hal-hal ekstrim dan impulsif sedangkan pada kondisi depresi seseorang mempunyai faktor resiko bunuh diri yang cukup tinggi. Gangguan bipolar disebabkan oleh faktor genetik, faktor sosial dan faktor biologis lainnya (Infrando Des, 2014). Data terkini menyatakan bahwa ada sekitar $15 \%$ hingga 20\% ODB yang mengalami kematian akibat bunuh diri [3].

Beberapa survivor bipolar mengaku bahwa sulit untuk mengontrol diri pada awal saat mereka terdiagnosa bipolar. Akan tetapi setelah melalui proses terapi dengan psikologi dan psikofarmaka dengan psikiater, kondisi mereka semakin membaik, mereka bisa lebih mudah mengendalikan mood, bisa kontak dengan realita dan kembali ke lingkungan masyarakat untuk aktif seperti manusia pada umumnya. Meskipun mereka sudah bisa menerima diri, mereka juga harus belajar menerima bagaimana oranglain memandang mereka. Hingga saat ini, banyak masyarakat yang mempunyai stigma negatif terhadap penderita ganggguan jiwa. Sehingga, banyak dari survivor bipolar yang kehilangan semangat, baik dalam bekerja, kuliah, sekolah, dan lain-lain.

Stigma negatif masyarakat terhadap penderita gangguan jiwa, banyak yang didasari dengan pengetahuan yang kurang mengenai gangguan jiwa [4]. Bahkan banyak masyarakat yang belum memahami gangguan bipolar itu sendiri. Akan tetapi, saat mengetahui bahwa bipolar adalah salah satu jenis gangguan jiwa, masyarakat banyak yang memilih untuk membangun stigma negatif. Masyarakat cenderung menjauhi, menganggap orang yang sudah terdiagnosa gangguan jiwa pasti bermasalah, tidak dapat diberdayakan, tidak produktif, dan tidak bisa menyelesaikan pekerjaan dengan baik. Padahal, seseorang yang terdiagnosa bipolar masih bisa bekerja dengan baik jika mampu mengelola emosinya. Stigma tersebut menyebabkan survivor bipolar merasa semakin rendah diri dan takut untuk kembali ke lingkungan sosial, terutama untuk terus bekerja dan berkarya.

Yogyakarta merupakan salah satu kota yang mempunyai prevalensi gangguan jiwa yang tinggi termasuk gangguan bipolar. Pada tahun 2016, Yogyakarta tercatat mempunyai lebih dari 10.554 orang dengan gangguan jiwa [4]. Yogyakarta mempunyai komunitas khusus untuk orang yang mengalami gangguan bipolar yaitu Bipolar Care Indonesia atau yang biasa disingkat dengan BCI simpul Jogja. Saat ini tercatat ada sekitar 300 anggota yang tergabung dalam grup media sosial facebook, sedangkan ada sekitar 70 survivor bipolar yang berinterkasi melalui grup Whats up. Sesuai dengan tagline BCI Simpul Jogja yaitu "Kami Berdaya Kami Berkarya”, BCI Simpul Jogja berharap survivor bipolar yang tergabung di BCI Simpul Jogja dapat mengembangkan diri. Selain mendapatkan pengobatan farmaka dan psikoterapi, mereka juga harus mendapatkan pembekalan khusus untuk bisa terus bekerja dan berkarya termasuk dalam berwirausaha [2]. 
Berdasarkan wawancara dengan anggota BCI Simpul Jogja, stigma dari masyarakat tidak jarang membuat mereka semakin rendah diri untuk kembali bekerja atau membuat usaha sendiri. Hampir sama dengan ketakutan yang umumnya terjadi, seseorang tidak ingin menjadi seorang wirausahawan karena merasa tidak mempunyai pengalaman dan modal [5]. Ditambah lagi mereka adalah orang dengan gangguan jiwa. Survivior bipolar mengaku membutuhkan dukungan dan pengetahuan untuk bisa keluar dari zona nyaman. Saat seseorang akan memulai sebuah usaha, merasa tidak ada yang mendukung dan takut untuk keluar dari zona nyaman [5].

Berdasarkan survey, mayoritas usia anggota BCI Simpul Jogja adalah usia produktif antara 20 hingga 40 tahun. Oleh karena itu, saat ini dianggap sebagai waktu yang paling tepat untuk memberikan edukasi yang lebih mengenai motivasi diri dan kewirausahaan sebagai salah satu upaya untuk mengembangkan diri para survivor bipolar menjadi "berdaya dan berkarya".

1.1 Perumusan Masalah

Berdasarkan uraian diatas, ada beberapa permasalahan yang dapat didentifikasikan sebagai berikut :

a. Stigma masyarakat menyebabkan anggota Bipolar Care Indonesia Simpul Jogja kesulitan dalam mendapatkan pekerjaan sehingga tidak produktif. Hal tersebut menumbuhkan keinginan survivor bipolar untuk berwirausaha

b. Kurangnya edukasi yang diberikan pada survivor bipolar karena selama ini hanya mencakup hal-hal yang berkaitan dengan psikologis atau terapi farmaka. Survivor bipolar membutuhkan edukasi yang berkaitan dengan wirausaha untuk memberdayakan diri.

c. Stigma negatif dan kurangnya dukungan dari masyakarat bagi para survivor bipolar.

a. Tujuan Kegiatan

1.2 Tujuan Kegiatan

Tujuan kegiatan pelatihan motivasi berwirausaha pada komunitas Bipolar Care Indonesia Simpul Jogja adalah :

a. Meningkatkan kepercayaan diri dan semangat survivor bipolar untuk bisa memulai usaha atau melanjutkan usaha. Peningkatan pemahaman survivor juga mengenai cara mengelola emosi dalam berwirausaha.

b. Peserta mampu melakukan perencanaan usaha dalam praktik Business Plan.

1.3 Manfaat Kegiatan

Manfaat kegiatan pelatihan motivasi berwirausaha pada komunitas Bipolar Care Indonesia Simpul Jogja adalah

a. Diharapkan survivor bipolar semakin percaya diri dan semangat untuk melanjutkan hidupnya dan semakin produktif.

b. Survivor bipolar diharapkan mampu mengelola emosi dan bisa berpikir positif

c. Survivor Bipolar dapat mengelola mood sehingga bisa lebih berkonsentrasi untuk pemberdayaan diri.

d. Diharapkan survivor bipolar mampu mempraktikan secara langsung perencanaan sebuah usaha dengan menyusun business plan, memahami cara membaca peluang usaha serta cara inovasi dalam berwirausaha. 


\section{METODE PENGABDIAN}

\subsection{Materi}

a. Pemateri adalah dosen dan praktisi psikolog klinis. Sedangkan pemateri kedua adalah praktisi binis yang bergelar master ekonomi manajemen.

b. Materi yang disampaikan dalam pelatihan ini adalah materi edukasi psikologi mencakup pengelolaan emosi serta motivasi diri. Sedangkan edukasi dari ekonomi manajemen mencakup praktik business plan serta cara membaca peluang serta inovasi wirausaha.

\subsection{Peserta Pelatihan}

Peserta dalam pelaksanaan kegiatan pengabdian pada masyarakat ini adalah :

\section{a. Survivior bipolar yang} mempunyai peminatan dalam bidang usaha dan sedang dalam kondisi stabil

b. Jumlah peserta dibatasi sebanyak 10 orang untuk memaksimalkan pemahaman peserta.

1.3 Metode yang digunakan

Dalam pelaksanaan kegiatan pengabdian kepada masyarakat ini, digunakan metode sebagai berikut :

\section{a. Metode Ceramah}

Metode ceramah didukung dengan tampilan yang menarik disertai dengan video sehingga memudahkan peserta untuk memahami apa yang disampaikan oleh pemateri

b. Metode Tanya Jawab dan Diskusi

Metode tanya jawab dan diskusi memudahkan peserta untuk bisa lebih memahami materi serta diskusi langsung tentang permasalahan yang dihadapi baik yang berhubungan dengan kondisi psikis maupun dalam perencanaan usaha.

c. Metode Praktik

Peserta melakukan perencanaan bisnis dengan mengerjakan beberapa worksheet yang dibimbing langsung oleh pemateri. Worksheet tersebut terdiri dari worksheet kondisi psikologis yang dibimbing langsung oleh psikolog. Sedangkan worksheet business plan dibimbing langsung oleh praktisi bisnis.

\section{HASIL DAN PEMBAHASAN}

Pelatihan dilakukan pada hari minggu, 15 September 2019 pukul 08.00 hingga pukul 16.00 di Ruang Kerja Coffee and Collaboration Yogyakarta. Berikut adalah grafik pemahaman peserta terhadap materi yang telah disampaikan :

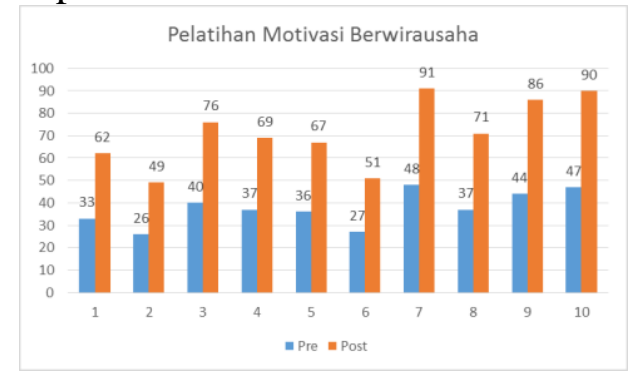

Gambar 1. Hasil Pre-Post

Pemahaman Peserta pada Materi Pelatihan

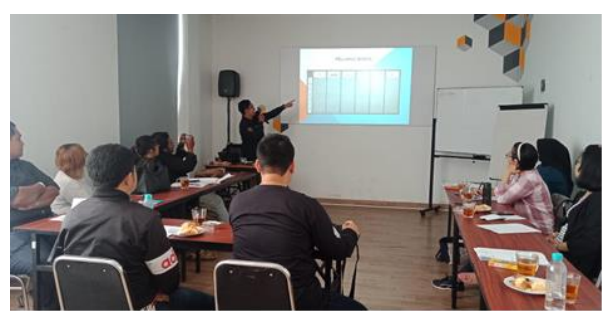

Gambar 2. Pemateri Kedua

Menyampaikan Inovasi Berwirausaha

Hasil dari pengabdian masyarakat berupa pelatihan berwirausaha pada survivor bipolar adalah sebagai berikut: a. Peserta mampu memahami materi yang disampaikan pemateri 
b. Peserta mampu membuat perencanaan usaha berupa business plan

c. Berdasar wawancara menunjukan meningkatnya kepercayaan diri dan motivasi peserta untuk survive, mandiri dan produktif

Secara keseluruhan pelatihan motivasi berwirausaha dapat dikatakan sesuai dengan yang diharapkan. Selain indikator diatas, keberhasilan juga dapat dilihat dari antusiasme peserta yang berkomitmen mengikuti acara dari awal hingga akhir sesi.

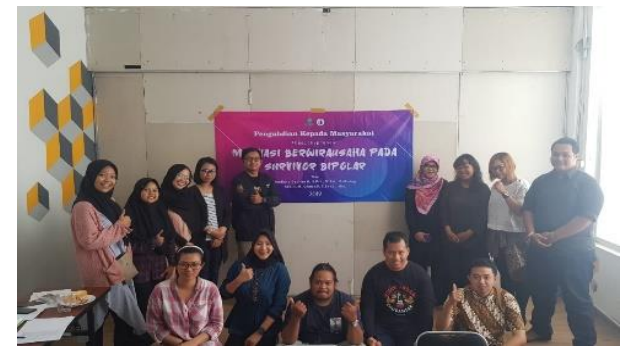

Gambar 3. Peserta dan Pemateri Pelatihan Motivasi Berwirausaha pada Komunitas Bipolar Care Indonesia

\section{SIMPULAN}

Berdasarkan pengabdian masyarakat yang telah dilaksanakan dapat disimpulkan bahwa :

a. Stigma negatif masyarakat pada orang dengan gangguan jiwa berdampak signifikan pada penderita gangguan jiwa, termasuk pada gangguan bipolar. Sehingga diperlukan kepedulian serta dukungan dari masyarakat untuk menciptakan kesejahteraan bersama.

b. Kegiatan pelatihan motivasi berwirausaha dapat terlaksana dengan baik dan lancar. Kegiatan ini disambut dengan antusias oleh anggota Bipolar Care Indonesia di Yogyakarta karena dianggap sebagai wujud kepedulian masyarakat terhadap komunitas BCI.

\section{UCAPAN TERIMA KASIH}

Penulis mengucapkan terimakasih kepada pihak-pihak yang telah membantu terlaksananya pengabdian masyarakat ini, yaitu :

1. Pengabdian masyarakat ini didanai oleh Universitas 'Aisyiyah Yogyakarta melalui program PKM (Pengabdian Kepada Masyarakat) Internal.

2. Ketua BCI Jogja dan Komunitas Bipolar Care Indonesia-Yogyakarta yang telah memberikan izin kepada penulis untuk memberikan pelatihan dalam komunitas BCI.

3. Owner Bleed.Lmt Clothing Yogyakarta selaku pemateri kewirausaahaan yang disampaikan dalam pelatihan

\section{DAFTAR PUSTAKA}

[1] Nevid, J. S. (2007). Psikologi Abnormal. Jurnal Kesehatan Jiwa. https://doi.org/10.1111/j.15338525.1976.tb01885.x

[2] M.Panggabean, L., \& Rona, D. (2015). Apakah Aku Bipolar?100 Tanya Jawab Dengan Psikiater + Bedah Kasus. Jakarta: PT Gramedia Pustaka.

[3] Maharani, D. (2016). Faktor Risiko Bunuh Diri pada Pasien Bipolar. Retrieved from http://lifestyle.kompas.com/read/20 16/06/23/110000823/Faktor.Risiko. Bunuh.Diri.pada.Pasien.Bipolar.

[4] Fakhruddin, M. (2017). Kasus Gangguan Jiwa di Yogyakarta Tinggi. Retrieved from https://nasional.republika.co.id/beri ta/nasional/umum/17/07/20/otcmoo 327-mengapa-kasus-gangguanjiwa-di-yogyakarta-tinggi .

[5] Hendro. (2011). Dasar-Dasar Kewirusahaan. In Erlangga.

[6] Infrando Des, D. (2014). Gangguan mood pada remaja. Majalah Kedokteran Nusantara. 